\title{
Beyazlatmanın diş ve çevre dokularda yaratabileceği yan etkiler ${ }^{*}$
}

\author{
Öznur Küçük(0000-0002-7303-0601) ${ }^{\alpha}$, Ayşe Diljin Keçeci(0000-0003-4738-6521) ${ }^{\alpha}$
}

Selcuk Dent J, 2019; 6: 110-119 Doi:10.15311/selcukdentj. 415997)

Başvuru Tarihi: 17 Nisan 2018 Yayına Kabul Tarihi: 05 Aralık 2018

\begin{abstract}
Öz
Beyazlatmanın diş ve çevre dokularda yaratabileceği yan etkiler

Toplumun diş beyazlatmaya olan ilgisi son yıllarda artmaktadır. Diş beyazlatma, restoratif tedavi seçenekleriyle karşılaştıııldığında en konservatif tedavi yöntemidir. Diş beyazlatmanın mekanizması hidrojen peroksitin parçalanmasından sonra açığa çıkan serbest oksijenin diş dokularında kromatik renk değişikliği oluşturduğu redoks reaksiyonuna bağlıdır. Beyazlatmanın yan etkileri; dental dokunun elastik modülünü ve mikrosertliğini modifiye eden HP (Hidrojen peroksit)'nin varlığına bağlanmaktadır. Beyazlatılmış dişlerin kırıma direncini etkileyebilen bu değişimler, doku yapısının değişimi ve dentindeki organik bileşenlerin indirgenmesine bağlı olabilir. Endodontik tedavi gören dişlerde bu durum diş yapısının zayıflaması nedeni ile daha kritik olabilir. Beyazlatma tedavisinde en fazla görülen, fakat geçici olan yan etki hassasiyettir. HP (Hidrojen peroksit) termal aktivasyon ile kombine kullanıldığında beyazlatmadan sonra daha fazla hassasiyet oluşur. Beş buçuk derecelik $\left(\mathrm{C}^{\circ}\right)$ bir intrapulpal sıcaklık artışı geri dönüşü olmayan pulpa hasarından kaçınmak için aşılmaması gereken eşik değeri olarak kabul edilmektedir. Bu derlemenin amacı, beyazlatıcı ajanların mine üzerindeki etkileri ve beyazlatma tedavilerinin yan etkilerini değerlendirmektir.
\end{abstract}

\section{ANAHTAR KELIMELER}

Beyazlatma, demineralizasyon, diş, yan etki

Günümüzde insanlar düzgün dizilmiş, açık renkli, doğal görünümlü dişlere sahip olmak için sıklıkla diş hekimlerine başvurmaktadırlar. Dişlerdeki şekil veya renk bozuklukları fonksiyon ve fonasyon kadar, estetik açıdan da önemlidir. Gelişmiş ülkelerde estetiğin neredeyse fonksiyonun önüne geçtiğini söylemek bile mümkündür. ${ }^{1}$ Vital diş beyazlatma, konservatif olmasından dolayı son yıllarda popülarite kazanmıştır. ${ }^{2}$

Diş renklenmeleri iç etkenlere bağlı oluşan renklenmeler (florozis, amelogenezis imperfekta, konjenital eritropoetik porfiria, endodontik tedavi sonrası renklenme), dış etkenlere bağlı oluşan renklenmeler (kötü oral hijyen, restorasyon varlığı, diyet alışkanlıkları,

\begin{abstract}
Adverse effects of bleaching in teeth and surrounding tissues

Public demand for tooth whitening has increased in recent years. Compared with restorative treatment choices, bleaching is the most conservative treatment option for discolored teeth. The mechanism of tooth bleaching relies on a redox reaction in which the release of free oxygen after hydrogen peroxide (HP) degradation recovers the chromatic alteration of dental tissues. The adverse effects of the bleaching procedure are attributed to the presence of HP, which can modify the microhardness and elasticity modulus of the dental tissues. These alterations may be related to the reduction of the organic components of dentin and to the changes in tissue morphology, which can influence the fracture resistance of bleached teeth. Such problem is even more critical in endodontically treated teeth, which present some degree of structural weakness. Tooth sensitivity has been identified as a common but transient side effect of bleach treatment. Sensitivity after bleaching is higher when HP is combined with thermal activation. An intrapulpal temperature increase of $5.5 \circ \mathrm{C}$ is nowadays regarded as the threshold value, which should not be exceeded to avoid irreversible pulp damage. The aim of this review, effects of bleaching agents on enamel and side effects of bleaching treatments were evaluated.
\end{abstract}

\section{KEYWORDS}

Bleaching, demineralization, tooth, side effect

kromojenik mikroorganizmalar) ve internalize renklenmeler olmak üzere üçe ayrılır $(\operatorname{Resim} 1) .{ }^{3}$ Diş beyazlatma işlemi, ulaşılabilen kaynaklarda 1848 yılında kalsiyum klorür ile uygulanmaya başlamış, günümüze değin kalsiyum hidroklorit, asetik asit, sodyum hipoklorit, oksalik asit, sülfürik asit, sodyum hipofosfat, hidrojen dioksit, sodyum peroksit, sodyum perborat, karbamit peroksit ve hidrojen peroksit gibi çok farklı ajanlar kullanılmıştır. ${ }^{4}$ Keçeci ${ }^{5}$ (2006) devital dişlerde ortaya çıkan renklenmelerin ağartıması amaciyla sodyum perborat (Starbrite, Dentramar, Hollanda) ve hidrojen peroksit (Opalescence Xtra, Ultradent, $A B D$ ) içerikli beyazlatma ajanlarını kullanarak 12'şer dişi tedavi etmiş ve iki yöntemi

\footnotetext{
${ }^{*}$ Bu derleme Süleyman Demirel Üniversitesi Bilimsel Araştırma Projeleri Koordinasyon Birimi (BAP)'nce desteklenen 4929-DU1-17.nolu uzmanlık tezi projesindeki bilgilerden derlenmiş, 10-13 Mayıs 2018 tarihleri arasındaki Türk Endodonti Derneği 8. Uluslararası Bilimsel Sempozyumu'nda sunulmuştur.

${ }^{\alpha}$ Süleyman Demirel Üniversitesi Diş Hekimliği Fakültesi Endodonti Anabilim Dalı, Isparta
} 
uygulama süresi ve uygulama kolaylığı açısından karşılaştırmıştır. Altı aylık aralıklarla 3 yıl boyunca takip edilen hastalarda renkte geriye dönüşün yanı sıra, diş sert dokularında kayıp, çatlak, servikal rezorbsiyon ve radyografik bulguların varlığı incelenmiştir. Opalescence Xtra ile beyazlatma ortalama iki dört gün arasında sağlanmış, ancak Starbrite uygulanan sekiz vakada sekizinci gün sonunda yeterli ağartma elde edilmemiştir. Günümüzde özellikle ofis tipi beyazlatma tekniği, en çok hidrojen peroksitin \%15-40 konsantrasyonlarının lastik örtü ile izolasyon altında ışıkla aktive ederek veya etmeyerek kullanılması ile elde edilmektedir. ${ }^{6,7}$

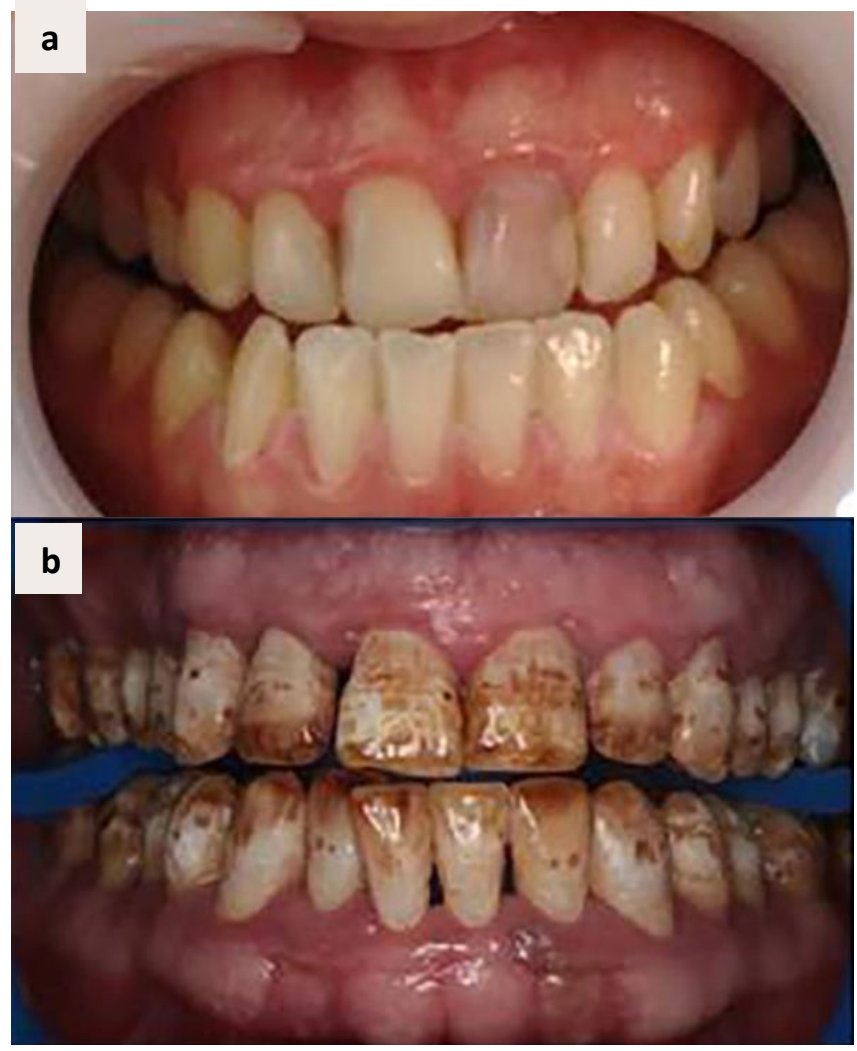

Resim 1.

a) Kök kanal tedavisi sonrasında devital dişte oluşan renklenme.

b) Fluorozise bağlı mine hipoplaziler, opasiteler ve kahverengi renklemeler ile karakterize olgu

Hidrojen peroksidin beyazlatma reaksiyonunu açıklayan kimyasal teoriye göre, aktif hidrojen peroksit su $\left(\mathrm{H}_{2} \mathrm{O}\right)$ ve oksijene $\left(\mathrm{O}_{2}\right)$ parçalanır ve kısa bir sürede serbest hidroksil radikalleri $(-\mathrm{OH})$ oluşur. ${ }^{8}$ Beyazlatma ajanı olan hidrojen peroksitin parçalanması sonucu oluşan serbest radikaller minenin interprizmatik aralıklarına difüze olur ve büyük organik moleküllerden kopardığı küçük molekülleri köpürme özelliği sayesinde yüzeye taşır. Bu serbest radikaller minede inorganik tuzlar arasında renklenmeye sebep olan organik moleküllerle reaksiyona girer. Bunun sonucu ışığı daha az yansıtan basit moleküller oluşur (Şekil 1). ${ }^{9}$
Diş beyazlatma ürünlerinin toksisitesi, genotoksisitesi, karsinojenitesi ve yan etkileri üzerine yapılmış klinik çalışmaların sınırlı sayıda olması ve çoğunlukla in vitro koşullarda yapılması, diş hekimlerinin diş beyazlatma işleminde daha seçici bir tutum sergilemelerini gerektirmektedir. ${ }^{10-12}$ Aksi takdirde işlem sırasında ve sonrasında diş ve çevre dokularda veya sistemik olarak ortaya çıkabilecek birçok yan etki söz konusudur. Beyazlatma ajanının etkisi dişlerin doğrudan aktif beyazlatma maddesine maruz bırakılma süresi ve konsantrasyonu ile ilgilidir. Uygulama süresi ve beyazlatıcı maddenin konsantrasyonu arttıkça oksidasyon işleminin etkinliği artarken renk değişimi ve yan etkiler artabilir. ${ }^{13}$ Devital beyazlatmanın yan etkilerin ortaya çıktığı dokulara göre sınıflandırması aşağıdaki gibidir:

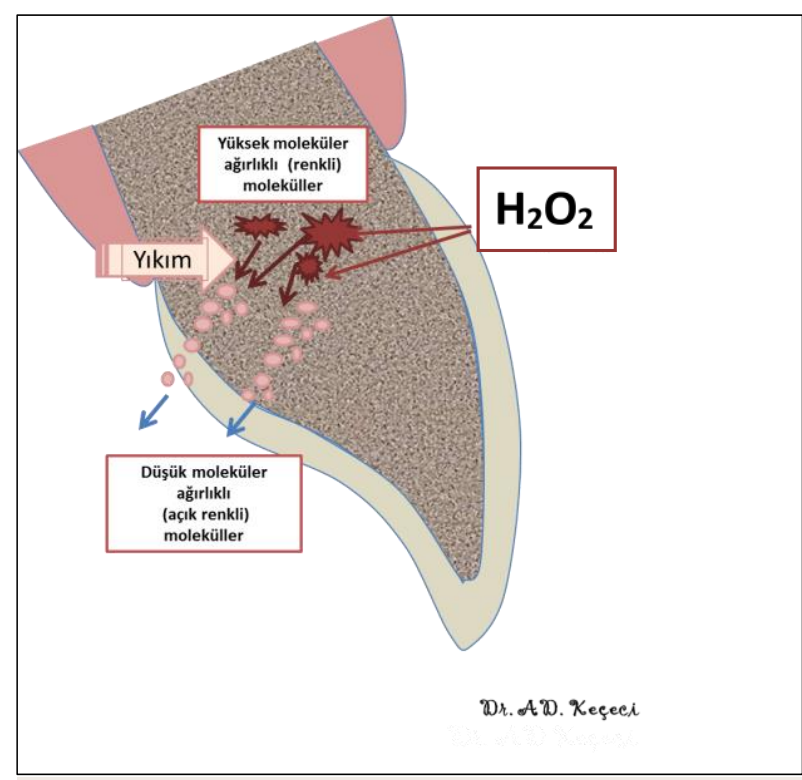

Şekil 1.

Devital beyazlatmanın etki mekanizmasının şematize edilmiş hali

Mine yapısında meydana gelen değişiklikler

Literatürde mine yüzeyine etkilerin incelendiği çalışmalarda uygulama miktarı ve şekline göre artan pörözite, demineralizasyon, protein konsantrasyonunda azalma, organik matris yıkımı, kalsiyum kaybı ve $\mathrm{Ca} / \mathrm{P}$ oranında değişim gibi etkiler bildirilmiştir. ${ }^{14-18}$

Haywood ve ark. ${ }^{14}$ (1990), karbamit peroksitle yapılan beyazlatma uygulamalarını SEM'le (scanning electron microscopy) incelediklerinde mine morfolojisinde değişiklik görülmediğini ya da çok az olduğunu bildirmişlerdir. Bunun aksine bazı çalışmalarda ise mine yapısında değişiklikler ${ }^{19}$, pitler, çukurcuklar, pörözite ve erozyon alanları gözlemlenmiş, bunun çözünme ve mineral kaybı ile meydana geldiği bildirilmiştir. ${ }^{20-23}$ Karbamit peroksit \% 16'lık konsantrasyonda kullanıldığında mine yüzeyinde mineral yapısının kaybı ve pürüzlülüğün artması gibi daha büyük değişikliklere neden olur. ${ }^{24}$ 
Atomik absorpsiyon spektrofotometresi ile yapılan bir çalışmada \% 10'luk karbamit peroksitin insan minesine 6 saat süre uygulanmasından sonra belirgin kalsiyum kaybı $\left(1,06 \mu \mathrm{g} / \mathrm{mm}^{2}\right)$ olduğu ve bunun 2,5 dakikalık kola uygulamasındaki kalsiyum kaybına eşit olduğu görülmüştür. ${ }^{17}$ Dişlerin organik matrisinde hidrojen peroksidin güçlü oksidizasyon etkisi beyazlatmadan sonra gözlemlenen değişikliklerde esas rolü oynar, mine ve dentinin sertliğinde azalma ve mineral içeriğinde değişikliklere de neden olabileceği belirtilmiştir. ${ }^{25}$ Demineralizasyon ve kalsiyumun kaybı beyazlatılmıs hidroksiapatitin inorganik yapısında oluşabilecek değişikliklerdendir. ${ }^{26}$ Rodrigues ve ark. ${ }^{27}$ (2005) 3 hafta süreyle farklı teknikler ile beyazlatma yapıldıktan sonra minenin mikrosertlik değerlerinin başlangıç değerlerine göre daha düşük olduğunu bildirmiştir. Araştırmacılar \% 37 KP (Karbamit peroksit) ile ofis tipi , \% $10 \mathrm{KP}$ ile ev tipi ve plasebo ajanın in situ uygulamalarında mikrosertlikte \% 3.46.8 arasında anlamlı azalma saptamışlardır. Zantner ve ark. $^{28}$ (2007), farklı beyazlatma işlemlerinden sonra minenin mikrosertliğinin beyazlatma ajanının tipi ve konsantrasyona göre değiştiğini tespit etmişlerdir. Buna karşın, \% 10'luk karbamit peroksit uygulanan bazı in vitro araştırmalarda minenin mikrosertliğinde değişiklik bulunamamıştır. ${ }^{29-31}$ Benzer çalışmalardaki farklı sonuçlar deney düzeneklerinde uygulama süresi, tükürük tampon varlığı, örnek sayısı gibi parametrelerin farklılıklarından kaynaklanmış olabilir.

Oltu ve Gürgan ${ }^{32}$ (2000), 6 hafta süreyle uygulanan \% 10 ve \% 16 'lık karbamit peroksidin yüzey morfolojisini etkilemediğini, 4 gün süreyle 30 dakika uygulanan \% $35^{\prime}$ lik hidrojen peroksidin ise etkilediğini belirtmiştir. Titley ve ark. $^{33}$ (1988), fosforik asit uygulamasını takiben uygulanan \% 35 'lik hidrojen peroksidin yüzeyde pörözite artışına neden olduğunu belirtmişlerdir.

Ogura ve ark. ${ }^{34}$ (2013) fotoirradyasyon ile ev tipi ve ofis tipi beyazlatmanın mine yapısına etkisini incelemişlerdir. Ev tipi beyazlatma uygulanan veya fotoirradyasyon yapılmadan beyazlatma uygulanan minede demineralizasyonun arttığını bildirilmişlerdir. Ofis tipi beyazlatma uygulanan minenin demineralizasyona karşı daha dirençli olduğu bildirilmiştir. Ofis tipi beyazlatma oluşan bu direncin uygulanmadan önce peroksitin minenin derin tabakalarına ulaşmamasından kaynaklandığı belirtilmiştir.

Beyazlatma uygulama seansları arasındaki sürenin uzun olması minenin remineralizasyonuna ve dişlerin mekanik özelliklerinin düzelmesine fırsat verir. ${ }^{35}$ Asidik solüsyonlara küçük miktarlarda kalsiyum ilavesinin minede madde kaybını azaltabileceği bildirilmiştir. ${ }^{36}$

\section{Adeziv dolguların bağlanmasına etkisi}

Mine ve dentine bağlanma hidrojen peroksidin varlığından dolayı beyazlatmayı takiben değişebilir. Beyazlatılmış minede rezin taglar sayıca daha azdır, daha az belirgin ve beyazlatılmamış mineye göre daha kısadır. ${ }^{37}$ Peroksit bazlı materyallerin minenin bağlanma dayanıklılığına ve yapısına etkileri ile ilgili araştırmalarda bağlanmanın düştüğü saptanmıştır. ${ }^{38,39}$ Klinik olarak bağlanma değerlerindeki bu düşüş önemlidir. Bazı yazarlar hidrojen peroksitin bağlanma üzerindeki olumsuz etkilerinin artık oksijenden kaynaklandığını bildirmiş ve bu durumun rezinin polimerizasyonunu engellediğini vurgulamışlardır. ${ }^{40}$

Beyazlatma tedavisi sonrasında azalmış bağlanma dayanıklılığı ile ilgili klinik problemlerden kaçınmak için pek çok yöntem önerilmektedir. Beyazlatma tedavisi sonrası restorasyon yapımının 24 saat ile 2 hafta geciktirilmesi en çok önerilen yöntemdir. ${ }^{41}$

\section{Dentin yapısında meydana gelen değişiklikler}

Dentin yüzeyine etkilerin incelendiği çalışmalarda ise dentin kırıma dayanımının azaldığı, dentinin germe ve makaslama kuvvetlerinde zararlı etkilerin oluştuğu, kalsiyum-fosfat oranının azaldığı ve servikal kök rezorbsiyonunun oluştuğu belirtilmiştir. ${ }^{18,42-44}$

48 saatte \% 10 ve \% $15^{\prime}$ lik KP ile yapılan in situ çalışmada dentin kırılma dayanımının azalmadığı belirtilmiştir. ${ }^{45}$ Pobbe ve ark. ${ }^{42}$ (2008) da \% 38'lik HP (Hidrojen peroksit)'yi 2 seans LED lazer (Light Amplification by Stimulated Emission of Radiation) sistemiyle aktive ederek uygulamanın dişin kırılma direncini azalttığını bildirmişlerdir. Götz ve ark. ${ }^{46}$ (2007) yaptıkları bir çalışmada \% 16 'ık hidrojen peroksitin diş yüzeyine uygulanmasından sonra mine veya dentinde yüzey ve yüzey altında yapısal veya kimyasal bir değişim olmadığını saptamışlardır.

Ağartma ajanları mine, dentin ve sementte morfolojik ve yapısal değişikliklere neden olur. Bu ajanlar, dokuda potasyum, sülfür, fosfor ve kalsiyum seviyelerinde değişikliğe neden olur ve dokunun organik inorganik komponentleri arasındaki oranı değiştirerek çözünürlüğü artıır. ${ }^{47} \% 30$ 'luk HP'nin dentinin germe ve makaslama kuvvetleri gibi biyomekanik özellikleri üzerinde de zararlı etkileri olduğu bildirilmiştir. ${ }^{48}$

Kawamoto ve Tsujimoto49 (2004)'ya göre diş beyazlamasından HP'in parçalanması sonucu açığa çıkan $\mathrm{OH}$ radikali sorumludur. Peritübüler ve intertübüler dentini etkileyerek organik kısmı çözer, geçirgenliği artıır, sertliği ve elastik modülü azaltır. Rotstein ve ark. ${ }^{18}$ (1997) tarafından yapılan çalışmada, dentinin kalsiyumfosfat oranının \% 10 karbamit peroksit ve \% 30 hidrojen peroksitle yapılan beyazlatmada önemli derecede azaldığı bulunmuştur. 
Çalışmalar, peroksitlerle yapılan beyazlatma işlemlerinin mineralize dentinin eğilme direncini ve modülünü azaltabileceğini göstermiştir. Sağlam sığır dentininde yaklaşık 140-220 MPa eğilme direnci mevcutken, eğilme modülü yaklaşık 12-14 MPa'dır. ${ }^{50}$ Maciel ve ark. ${ }^{51}$ (1996) dekalsifiye insan dentin matrisinin sudaki elastik modülünün 5-7 $\mathrm{MPa}$ arasında değişebileceğini belirtmiştir. Berger ve ark. $^{50}$ (2012) sığır dişlerinde demineralize dentinin (kontrol grubu) elastik modülü yaklaşık $3 \mathrm{MPa}$ bulmuştur ki, bu insan dentini elastik modülü değerinin yarısını temsil etmektedir. Sonuçlar, yaklaşık 3 MPa bulmuştur ki, bu insan dentini elastik modülü değerinin yarısını temsil etmektedir. Sonuçlar, insan ve sığır dişleri arasındaki bileşimsel ve morfolojik farklılıkları kısmen yansıtmaktadır. Araştırmacılar, numuneler beyazlatıldıktan hemen sonra test edildiğinde demineralize dentin matrislerinin elastik modülünde bir azalma gözlemlemişlerdir. Bununla birlikte, su içinde 14 günlük depolamadan sonra, ağartılmış grupların çoğunun, ağartılmamış kontrol grubuna benzer bir elastik modülü göstermesi remineralizasyonun mümkün olduğunu açıklamaktadır. Son çalışmalar hidrojen peroksit ve karbamit peroksitin MMP (matrix metalloproteinaz) kollajenlerinin parçalanmasını artırdığını göstermiştir. ${ }^{52}$ Beyazlatmadan sonra dentinin mikrosertliği azalmıştır fakat bunun klinik olarak bir önemi olmadığı da belirtilmiştir. ${ }^{53}$

Lado ve ark. ${ }^{54}$ (1983) beyazlatma ajanlarının dentin tübüllerine nüfuz edebileceğini ve mine ile sement arasındaki servikal bölgede dentini denatüre edebileceğini bildirmişlerdir. Denatüre dentin yabancı bir doku olarak immünolojik cevabı tetikleyebilir. Bazı araştırmacılar, beyazlatma materyallerinin dentin tübüllerine nüfuz ettiğini ve servikal kök rezorpsiyonunu takiben bir enflamatuar süreci başlattığını iddia etmiştir. ${ }^{55,56}$ Dentin hidrojen peroksite geçirgendir ve bu difüzyon oranı \% 82'ye kadar ulaşır, bu da morfolojik ve kimyasal varyasyonlara neden olabilir. ${ }^{57}$ Endodontik olarak tedavi edilen dişlerin intrakoronal beyazlatması servikal kök rezorbsiyonuna sebep olabilir. Bunun nedeni beyazlatma ajanının dentin tübülleri boyunca periodontal dokulara geçmesi olarak açıklanabilir. ${ }^{58}$

Sonuç olarak hidrojen peroksit yalnız veya sodyum perborat ile birlikte kullanıldığında dentin permabilitesini artırır, dentinin kimyasal yapısını değiştirir ve diş sert dokusunun fiziksel özelliklerini zayıflatır. ${ }^{49}$

\section{Pulpa yapısında meydana gelen değişiklikler}

Diş duyarlılığının ekspoze kök yüzeyi, dentin ya da çürükle ilişkili olmadığına inanıır, fakat duyarlılık; mine ve dentinden pulpanın içerisine hidrojen peroksitin kolay bir şekilde geçişiyle açıklanabilir. Bu, pulpal sinirleri etkileyen enflamasyonla sonuçlanabilir. ${ }^{59}$ Hidrojen peroksitin penetrasyon çalışmalarında bileşiklerin çekilmiş dişlerin mine ve dentininden pulpa odasına kolaylıkla ulaştığı rapor edilmiştir. ${ }^{60,11}$ Hidrojen peroksit pulpa enzimlerine etki ederek duyarlılığa sebep olmakta ve hücrelerde değişikliklere neden olmaktadır. ${ }^{23}$ Fuss ve ark. $^{61}$ (1989) beyazlatma ajanlarının dentin tübülleri boyunca pulpa odasına infiltrasyonunu incelemişler ve kök yüzeyindeki pH değişimini ölçmüşlerdir. 7 ile 9 gün arasında eksternal yüzeyde önemli pH artışı olduğunu bildirmişlerdir. Özdemir62 (2008) in vitro deneylerde kaydedilen maksimum penetrasyon miktarlarının Whiteness HP Maxx için 16,2 $\mu \mathrm{m}$, Opalescence Xtra için ise 18,3 $\mu \mathrm{m}$ olduğunu belirtmiştir.

Pulpa üzerindeki araştırmalar sınırlı olmakla birlikte bunların çoğu pulpada reversibl etkilerin varlığından söz etmektedir. ${ }^{63}$ Pugh ve ark. ${ }^{64}$ (2005) hidrojen peroksitin \% 3.5, \% 7 ve \% 12'lik konsantrasyonlarının pulpaya penetrasyonunu in vitro koşullarda 98 saat boyunca incelemiş ve 23-26 mikrogramlık penetrasyon düzeyi belirlemişlerdir. Araştırıcılar pulpadan elde edilen bu değerlerden, hidrojen peroksidin pulpal enzimleri inhibe etmesini beklemediklerini belirtmişlerdir. \% 30'luk hidrojen peroksit $50^{\circ} \mathrm{C}$ ısı ile mine yüzeyine uygulandığında pulpa odasına geçen hidrojen peroksit miktarı yaklaşık olarak mikrogramlarla ifade edilmektedir. ${ }^{65}$ Aşırı ISI kullanmanın pulpa nekrozu ile sonuçlanabileceği bilinmektedir. ${ }^{23}$

Robertson ve ark. ${ }^{66}$ (1980) \% 35'lik hidrojen peroksit solüsyonunun $5 \mathrm{dk}$ süreyle iki kez uygulanmasından sonra $\left(54^{\circ} \mathrm{C}\right)$ pulpada hafif bir enflamasyon oluştuğunu bildirmişlerdir. Özdemir ${ }^{62}$ (2009) ortodontik amaçla çekim yapılacak 12-19 yaşlarındaki 5 hastanın 8 dişine iki farklı ağartma ajanı (Whiteness HP Maxx (Whiteness HP, FGM, Joinville Brasil), Opalescence Xtra (Ultradent Products, South Jordan,USA) aynı hastada aynı süreler olacak şekilde sırasıyla $5,10,20$ veya 30 dakika uygulanmıştır. Kontrol dişlerinde hafif düzeyde ödem izlenirken, deney dişlerinde ileri derecede ödem, odontoblastların basıklaşması, kapiller damarlarda konjesyon ve staz, odontoblastların tübül ağızlarına yaklaşması, hücreden fakir tabakanın izlenmemesi gibi histolojik bulgular dikkati çekmiştir. Ancak hiç bir örnekte enflamasyon gelişimi ya da geri dönüşümsüz bir durum gözlenmemiştir. 
Seale ve ark.'nın ${ }^{67}$ (1981) yaptığı bir çalışmada hidrojen peroksitin tek başına veya ISı ile beraber uygulandığı beyazlatmalarda kanin dişlerinde histolojik hasar tespit edildiği, ancak 60 günde pulpanın normale döndüğü belirtilmiştir. Ofis tipi beyazlatmada kullanılan ışıkların aktivasyonuyla ilgili temel sorun ISı oluşması ve bu ısının pulpayı etkilemesidir. Bazı çalışmalarda beyazlatma lambalarının sebep olduğu sıcaklık artışının pulpada irreversibl zarar oluşturacak eşik değerin 5.5 ${ }^{\circ} \mathrm{C}$ altında olduğu bulunmuştur. ${ }^{3,68}$

Karbamit peroksitin \% 10'luk konsantrasyonu \% 16'llk konsantrasyonuna göre pulpa hücrelerine daha az toksiktir ${ }^{69}$ Düşük güç ve yüksek güçteki diyot lazerlerle yapılan beyazlatma uygulamaları, ışıkla aktive olmayan yüksek konsantrasyonlu hidrojen peroksit ile yapılan beyazlatma ile karşıllaştıııldığında daha yüksek bir ağartma etkinliği ile sonuçlanmaz. Bununla birlikte, beyazlatma jelinin pulpanın termal hasarının oluşabileceği bir seviyede ısıtılmaması için yüksek güçlü diyot lazerlerin kullanılmasına özen gösterilmelidir. Kimyasal reaksiyon oranını artırmak için bir diğer önemli faktör, $10^{\circ} \mathrm{C}$ lik bir yükselişin reaksiyon oranını ikiye katlayabilmesidir. ${ }^{11}$

\section{Hassasiyet oluşturması}

Mine hidrojen peroksit veya karbamid peroksiti sızdırmaz bir yapı değildir. ${ }^{70}$ Hidrojen peroksit ve karbamit peroksit mine ve dentine penetre olur, hassasiyete sebep olur. ${ }^{71}$ Diş hassasiyeti beyazlatmanın en sık bildirilen yan etkisidir. Evde beyazlatma sürecinde genellikle hastaların üçte ikisinde duyarlılık görülmesine karşlık, beyazlatma boyunca bazı kişilerdeki diş duyarlıı̆̆ çok az araştırmada dikkat çeken bir problemdir ve genellikle 1-4 gün devam eder. ${ }^{72}$

Rastgele klinik çalışmalara göre, beyazlatma tedavilerini takiben oluşan diş hassasiyetlerinin ön dişlerle sınırlı ve bu yan etkinin yoğunluğunun doğrudan mine ve dentinin kalınlığına bağlı olduğu tespit edilmiştir. ${ }^{73,27}$ Rodrigues ve ark. ${ }^{27}$ (2005), \% 38'lik hidrojen peroksit (HP) jeli ile beyazlatma yaptıktan sonra kanin ve kesici dişlerin geçirgenliğinin belirgin olarak arttığını, buna karşın premolarların hiçbir değişiklik göstermediğini ya da hafif bir değişiklik göstermiş olduğunu belirtmişlerdir. İnsan dişlerindeki histopatolojik çalışmalarda, \% 35-38 HP jel ile yapılan beyazlatma sonucunda, mandibular kesici dişlerin pulpa dokusunda yoğun doku düzensizliği, odontoblastik tabaka bozulması, nekroz alanları ve yoğun inflamatuar reaksiyon ile karakterize hasara neden olduğunu gösterilmiştir. ${ }^{74}$ Tersine, aynı beyazlatma tedavisine tabi tutulan premolarlar ciddi histolojik pulpa değişiklikleri göstermemiştir. ${ }^{75}$ Hidrojen peroksitin hücrelerle direkt teması pulpal enzim aktivitesini önemli düzeyde inhibe edebilir ve hipersensitiviteye yol açabilir. ${ }^{65}$
Bazı çalışmalar beyazlatma maddelerinin konsantrasyonundaki artışın diş hassasiyeti üzerinde daha yüksek bir etkiye sahip olduğunu göstermiştir. Karbamit peroksit ile yapılan beyazlatmada, ışık kaynaklarından bağımsız olarak HP ile yapılan beyazlatmaya göre daha az hassasiyet oluşmuştur. ${ }^{76,77}$

\section{Periodonsiyumda meydana gelen değişiklikler}

Ağartma ajanlarına uzun süre maruz kalmanın olası patolojik etkileri vardır. Dişeti ve oral yumuşak dokularda irritasyon ve ülserasyon oluşumuna sebep olabilir. Ağartma ajanlarının insan dişeti fibroblastları üzerine toksik etkiye sahip olduğu ve birçok hücresel fonksiyonu inhibe ettiği belirtilmiştir. Ancak ağız ortamında bulunan HP'yi yıkan enzimlerin, oral dokuları ve komponent hücreleri bu potansiyel toksik etkilerden koruyacağı ileri sürülmektedir. ${ }^{78}$ Ayrıca ağartma ajanından kaynaklanan oksijen, kanal duvarlarından sızıntı yaparak periapikal dokular boyunca ilerler ve ağrı oluşumuna sebep olabilir. ${ }^{79}$

Hidrojen peroksidin yüksek konsantrasyonu (\% 30-35) mukozal membran için yakıcıdır ve dişetinde beyazlama ve yanmaya sebep olabilir. Deney hayvanlarında, dişetinin \% 1'lik hidrojen perokside maruz bırakılması epitelde hasar oluşturmuş ve subepitelyal dokuda akut inflamasyona sebep olmuştur. ${ }^{80}$ Taşıyıcı plaklarda \% 10 karbamit peroksidin kullanıldığı klinik deneylerde tedavi süresince gingival irritasyon rapor edilmiştir. Taşıyıcıların neden olduğu mekanik irritasyonla beraber beyazlatma ajanlarının dokularda meydana getirdiği irritasyondan da söz edilebilir. ${ }^{81}$ Luque Martinez ve ark.'nın ${ }^{82}$ (2016) yaptığı bir çalışmada HP ve KP ev tipi beyazlatmadan sonra gingival irritasyon ve hassasiyet açısından benzer değişiklikler gösterdiği bildirilmiştir.

Hidrojen peroksit yutulduğunda ortaya çıkan akut etkiler, yutulan miktara ve hidrojen peroksit solüsyonunun konsantrasyonuna bağlıdır. İstem dışı \% 35'lik hidrojen peroksit yutan bireylerde; kusma, siyanoz, konvülsiyon, solunum sorunları ve hatta ölüm bulguları kaydedilmiştir. ${ }^{83}$ Gaz embolisi nedeniyle serebral enfarktüs ve kalpte iskemik değişiklikler de gözlenmiştir. ${ }^{84}$ Beyazlatma uygulamalarının yan etkileri aşağıdaki tabloda özetlenmiş̧ir (Tablo 1).

\section{SONUÇ}

Diş beyazlatma tekniklerinin uygulanması giderek yaygınlaşmakta, hem hasta hem de hekim için ciddi avantajlar sağlamaktadır. Dişlerin beyazlatılmasında kullanılan teknikler diş hekimi kontrolünde uygulandığında daha başarılı, etkin ve güvenli tedaviler ortaya çıkacaktır. Olası yan etkilerden kaçınmak için düşük konsantrasyonda peroksit içeren preparatlar tercih edilmeli, uzun beyazlatma periyotlarından kaçınılmalıdır. Beyazlatma materyallerinin yan etkileri ile ilgili ilave çalışmalar yapılmalıdır. 
Tablo 1.

Beyazlatmanın yan etkileri

\begin{tabular}{|c|c|c|c|}
\hline & Etiyoloji & Etki & Açıklama \\
\hline Sistemik & Yutma & $\begin{array}{l}\text { Kusma, siyanoz, konvülsiyon, solunum } \\
\text { sorunları, serebral enfarktüs ve kalpte } \\
\text { iskemik değişiklikler }^{84}\end{array}$ & \\
\hline \multirow{6}{*}{ Mine } & Karbamit peroksit & $\begin{array}{l}\text { Pitler, çukurcuklar, pörözite ve erozyon ve } \\
\text { mineral kaybı }{ }^{20-23}\end{array}$ & SEM çalışması \\
\hline & 10'llk Karbamit peroksit & Mineral kaybı ve pürüzlülük artışı ${ }^{24}$ & SEM çalışması \\
\hline & \%10'luk karbamit peroksit & Belirgin kalsiyum kaybı $\left(1.06 \mu \mathrm{g} / \mathrm{mm}^{2}\right)^{17}$ & $\begin{array}{l}\text { Atomik Absorbsiyon } \\
\text { Spektrofotometre } \\
\text { çalışması }\end{array}$ \\
\hline & $\begin{array}{l}\% 37 \mathrm{KP} \text { ile ofis tipi, } \% 10 \mathrm{KP} \text { ile } \\
\text { ev tipi ve plasebo ajanı }\end{array}$ & $\% 3,4-6,8$ arasında mikrosertlikte azalma ${ }^{27}$ & in situ çalışma \\
\hline & $\%$ 10'luk karbamit peroksit & $\begin{array}{l}\text { Minenin mikrosertliğinde değişiklik } \\
\text { bulunamamışş-31 }\end{array}$ & in vitro araştırmalarda \\
\hline & $\begin{array}{l}\text { Ev tipi (\%10 CP) ve ofis tipi (\%35 } \\
\text { HP) beyazlatma }\end{array}$ & $\begin{array}{l}\text { Ev tipi beyazlatma beyazlatmada daha çok } \\
\text { minede demineralizasyon }{ }^{34}\end{array}$ & Fotoirradyasyon \\
\hline \multirow{7}{*}{ Dentin } & $\begin{array}{l}48 \text { saat süreyle } \% 10 \text { ve } \% 15^{\prime} \text { lik } \\
\text { KP uygulaması }\end{array}$ & Azalmamış dentin kırıma dayanımı ${ }^{45}$ & in situ \\
\hline & $\begin{array}{l}\text { \%38 lik HP'in } 2 \text { seans } \\
\text { uygulaması }\end{array}$ & Azalmış dentin kırılma dayanımı ${ }^{42}$ & LED Lazer \\
\hline & $\% 16$ 'lık hidrojen peroksit & $\begin{array}{l}\text { Mine ve dentinde yapısal ve kimyasal } \\
\text { değişim görülmemiş }{ }^{46}\end{array}$ & \\
\hline & $\% 10 \mathrm{KP}$ ve $\% 30 \mathrm{HP}$ & Azalmış kalsiyum-fosfat oranı ${ }^{18}$ & \\
\hline & \%30'luk HP & $\begin{array}{l}\text { Dentinin germe ve makaslama kuvvetlerine } \\
\text { zararlı etkiler }{ }^{49}\end{array}$ & \\
\hline & Beyazlatma ajanları & Servikal kök rezorbsiyonu ${ }^{58}$ & \\
\hline & \%35'lik HP & Kök rezorbsiyonu ${ }^{44}$ & \\
\hline \multirow{6}{*}{ Pulpa ve Hassasiyet } & Beyazlatma ajanları & $\begin{array}{l}7 \text { ile } 9 \text { gün arasında eksternal yüzeyde } \\
\text { önemli pH artış }{ }^{61}\end{array}$ & in vitro \\
\hline & \%3,5, \%7 ve \%12'lik HP & $\begin{array}{l}98 \text { saat sonunda } 23-26 \text { mikrogramlık pulpa } \\
\text { penetrasyonu }^{64}\end{array}$ & \\
\hline & $\begin{array}{l}\% 35 \text { 'lik HP solüsyonu } 5 \mathrm{dk} \\
\text { süreyle iki kez }\end{array}$ & $\begin{array}{l}\text { Pulpada hafif bir enflamasyon ( } 54 \\
\text { derecede })^{85}\end{array}$ & \\
\hline & $\% 10$ ve \%16'lık KP & $\begin{array}{l}\% 10^{\prime} \text { luk konsantrasyonu } \% 16^{\prime} \text { 'ık } \\
\text { konsantrasyonuna göre pulpa hücrelerine } \\
\text { daha az toksik }\end{array}$ & \\
\hline & \%38'lik HP & $\begin{array}{l}\text { Kanin ve kesici dişlerin geçirgenliğinde } \\
\text { belirgin artış }\end{array}$ & \\
\hline & \%10'luk KP & Diş hassasiyeti ${ }^{44}$ & \\
\hline \multirow{3}{*}{ Periyodonsiyum } & $\% 10 \mathrm{KP}$ & Gingival irritasyon ${ }^{81}$ & Taşıyıcı plaklar \\
\hline & HP ve KP ajanları & Gingival irritasyon ve hassasiyet ${ }^{82}$ & Ev tipi beyazlatma \\
\hline & \%38'lik HP & Hassasiyet ve gingival irritasyon ${ }^{44}$ & $\begin{array}{l}\text { Tek başına veya ısı ve ışık } \\
\text { ile aktivasyon }\end{array}$ \\
\hline \multirow[t]{2}{*}{ Dolguların bağlanması } & Beyazlatma & $\begin{array}{l}\text { Beyazlatılmış minede rezin taglar sayıca } \\
\text { daha az, daha az belirgin ve beyazlatılmamış } \\
\text { mineye göre daha } \text { kısa }^{37}\end{array}$ & \\
\hline & Peroksit bazlı materyaller & $\begin{array}{l}\text { Minenin bağlanma dayanıklıı̆ında } \\
\text { düşüşక38,39 }\end{array}$ & \\
\hline
\end{tabular}




\section{KAYNAKLAR}

1. Elif i, Bayrak Ş. Diş ağartma yöntemleri ve komplikasyonları. Ondokuz Mayıs Üniversitesi Diş Hekimliği Fakültesi Dergisi. 2009; 10(3): 125-33.

2. Kihn PW. Vital tooth whitening. Dent Clin North Am. 2007; 51(2): 319-31.

3. Sulieman M. An overview of tooth discoloration: extrinsic, intrinsic and internalized stains. Dent update. 2005; 32(8): 463-4, 6-8, 71.

4. Alqahtani MQ. Tooth-bleaching procedures and their controversial effects: A literature review. Saudi Dent J. 2014; 26(2): 33-46.

5. Keçeci D. Devital dişlerin ıntrakoronal ağartmasında kullanılan iki farklı materyalin klinik etkinliğinin karşılaştıııması. SDÜ Tıp Fakültesi Dergisi. 2006; 13(3): 4-8.

6. Haywood VB. Current status of nightguard vital bleaching. Compendium. 2000; 21(28): S10-S7.

7. Ontiveros JC. In-office vital bleaching with adjunct light. Dent Clin. 2011; 55(2): 241-53.

8. Fasanaro TS. Bleaching teeth: history, chemicals, and methods used for common tooth discolorations. J Esthet Restor Dent. 1992; 4(3): 71-8.

9. Karadaş M, Seven N. Vital Dişlerde Beyazlatma. Atatürk Üniversitesi Diş Hekimliği Fakültesi Dergisi. 2014; 9(9): 126-35.

10.Koruk DC, Kırzıoğlu Z. Diş beyazlatma tedavisinin güvenilirliği. Ondokuz Mayıs Üniversitesi Diş Hekimliği Fakültesi Dergisi. 2010; 11(1): 29-37.

11.De Moor RJG, Verheyen J, Verheyen P, Diachuk A, Meire MA, De Coster PJ, et al. Laser teeth bleaching: evaluation of eventual side effects on enamel and the pulp and the efficiency in vitro and in vivo. Scientific World Journal. 2015; 2015: 6-7.

12.Jordao-Basso KCF, Kuga MC, Dantas AAR, Tonetto MR, Lima SNL, Bandeca MC. Effects of alphatocopherol on fracture resistance after endodontic treatment, bleaching and restoration. Braz Oral Res. 2016; 30(1).

13.Leonard RH, Sharma A, Haywood vB. Use of different concentrations of carbamide peroxide for bleaching teeth: An in vitro study. Quintessence Int. 1998; 29(8): 503-7.

14. Haywood VB, Leech T, Heymann HO, Crumpler D, Bruggers K. Nightguard vital bleaching: effects on enamel surface texture and diffusion. Quintessence Int. 1990; 21(10).

15.Azrak B, Callaway A, Kurth $P$, Willershausen B. Influence of bleaching agents on surface roughness of sound or eroded dental enamel specimens. J Esthet Restor Dent. 2010; 22(6): 391-9.

16.Xu B, Li Q, Wang Y. Effects of $\mathrm{pH}$ values of hydrogen peroxide bleaching agents on enamel surface properties. Oper Dent. 2011; 36(5): 554-62.

17. McCracken MS, Haywood VB. Demineralization effects of 10 percent carbamide peroxide. J Dent. 1996; 24(6): 395-8.
18. Rotstein I, Mor C, Arwaz JR. Changes in surface levels of mercury, silver, tin, and copper of dental amalgam treated with carbamide peroxide and hydrogen peroxid e in vitro. Oral Surg, Oral Med, Oral Pathol, Oral Radiol, Endod. 1997; 83(4): 5069.

19.Bitter NC. A scanning electron microscopy study of the effect of bleaching agents on enamel: a preliminary report. J Prosthet Dent. 1992; 67(6): 852-5.

20.McGuckin RS, Babin J, Meyer B. Alterations in human enamel surface morphology following vital bleaching. J Prosthet Dent. 1992; 68(5): 754-60.

21. Akal $\mathrm{N}$, Over $\mathrm{H}$, Olmez A, Bodur $\mathrm{H}$. Effects of carbamide peroxide containing bleaching agents on the morphology and subsurface hardness of enamel. J Clin Pediatr Dent. 2001; 25(4): 293-6.

22. Wandera A, Feigal RJ, Douglas WH, Pintado MR. Home-use tooth bleaching agents: an in vitro study on quantitative effects on enamel, dentin, and cementum. Quintessence Int. 1994; 25(8).

23. Haywood VB, Heymann HO. Nightguard vital bleaching: how safe is it? Quintessence Int. 1991; 22(7): 775-82.

24.Soares DG, Ribeiro APD, Sacono NT, Loguércio $A D$, Hebling J, Costa CAdS. Mineral loss and morphological changes in dental enamel induced by a $16 \%$ carbamide peroxide bleaching gel. Braz Dent J. 2013; 24(5): 517-21.

25.Chng H, Ramli H, Yap A, Lim C. Effect of hydrogen peroxide on intertubular dentine. $\mathrm{J}$ Dent. 2005; 33(5): 363-9.

26. Rotstein I, Dankner E, Goldman A, Heling I, Stabholz A, Zalkind M. Histochemical analysis of dental hard tissues following bleaching. J Endod. 1996; 22(1): 23-6.

27. Rodrigues JA, Marchi GM, Ambrosano GM, Heymann HO, Pimenta LA. Microhardness evaluation of in situ vital bleaching on human dental enamel using a novel study design. Dent Mater. 2005; 21(11): 1059-67.

28.Zantner C, Beheim-Schwarzbach N, Neumann K, Kielbassa AM. Surface microhardness of enamel after different home bleaching procedures. Dent Mater. 2007; 23(2): 243-50.

29. Lopes GC, Bonissoni L, Baratieri LN, Vieira LCC, Monteiro S. Effect of bleaching agents on the hardness and morphology of enamel. J Esthet Restor Dent. 2002; 14(1): 24-30.

30. Murchison D, Charlton D, Moore B. Carbamide peroxide bleaching: effects on enamel surface hardness and bonding. Oper Dent. 1991; 17(5): 181-5.

31.Potočnik I, Kosec L, Gašperšič D. Effect of $10 \%$ carbamide peroxide bleaching gel on enamel microhardness, microstructure, and mineral content. J Endod. 2000; 26(4): 203-6. 
32. Oltu Ü, Gürgan S. Effects of three concentrations of carbamide peroxide on the structure of enamel. J Oral Rehabil. 2000;27(4):332-40.

33. Titley K, Torneck CD, Smith D. The effect of concentrated hydrogen peroxide solutions on the surface morphology of human tooth enamel. J Endod. 1988;14(2):69-74.

34.Ogura K, Tanaka R, Shibata Y, Miyazaki T, Hisamitsu $\mathrm{H}$. In vitro demineralization of tooth enamel subjected to two whitening regimens. J Am Dent Assoc. 2013;144(7):799-807.

35. Khoroushi M, Mazaheri $\mathrm{H}$, Manoochehri A. Effect of CPP-ACP application on flexural strength of bleached enamel and dentin complex. Oper Dent. 2011;36(4):372-9.

36. Hughes J, West N, Parker D, Van Den Braak M, Addy M. Effects of $\mathrm{pH}$ and concentration of citric, malic and lactic acids on enamel, in vitro. $J$ Dent. 2000;28(2):147-52.

37. Nathoo S, Chmielewski M, Kirkup R. Effects of Colgate Platinum Professional Toothwhitening System on microhardness of enamel, dentin, and composite resins. Compendium (Newtown, Pa) Supplement. 1993(17):S627-30.

38. Shannon H, Spencer P, Gross K, Tira D. Characterization of enamel exposed to $10 \%$ carbamide peroxide bleaching agents. Quintessence Int. 1993;24(1):39-44.

39. Titley K, Torneck C, Ruse N. The effect of carbamideperoxide gel on the shear bond strength of a microfil resin to bovine enamel. J Dent Res. 1992;71(1):20-4.

40. Titley K, Torneck C, Smith D, Chernecky R, Adibfar A. Scanning electron microscopy observations on the penetration and structure of resin tags in bleached and unbleached bovine enamel. $J$ Endod. 1991;17(2):72-5.

41.Garcia-Godoy F, Dodge W, Donohue M, O'quinn J. Composite resin bond strength after enamel bleaching. Oper Dent. 1993; 18: 144-.

42. da Silva Pobbe PdO, Viapiana R, Souza-Gabriel AE, Marchesan MA, Sousa-Neto MD, Silva-Sousa YTC, et al. Coronal resistance to fracture of endodontically treated teeth submitted to light-activated bleaching. J Dent. 2008;36(11):935-9.

43. Chng $\mathrm{H}$. Update on materials used in intracoronal bleaching. Annals of the Royal Australasian College of Dental Surgeons. 2002; 16: 147-50.

44. Sarrett DC. Tooth whitening today. J Am Dent Assoc. 2002;133(11):1535-8.

45.Tam L, Bahrami P, Oguienko O, Limeback H. Effect of $10 \%$ and $15 \%$ carbamide peroxide on fracture toughness of human dentin in situ. Oper Dent. 2013;38(2):142-50.

46. Götz H, Klukowska MA, Duschner H, White DJ. Physical, morphological, and micro-Raman chemical studies on bleaching strip effects on enamel, coronal dentin, and root dentin. J Clin Dent. 2006;18(4):112-9.
47.Lewinstein I, Hirschfeld Z, Stabholz A, Rotstein I. Effect of hydrogen peroxide and sodium perborate on the microhardness of human enamel and dentin. J Endod. 1994; 20(2): 61-3.

48. Chng HK, Palamara JE, Messer HH. Effect of hydrogen peroxide and sodium perborate on biomechanical properties of human dentin. $\mathrm{J}$ Endod. 2002;28(2):62-7.

49. Kawamoto K, Tsujimoto $\mathrm{Y}$. Effects of the hydroxyl radical and hydrogen peroxide on tooth bleaching. J Endod. 2004; 30(1): 45-50, 53.

50.Berger SB, Pavan S, Vidal CdMP, Santos PHD, Giannini M, Bedran-Russo AK. Changes in the stiffness of demineralized dentin following application of tooth whitening agents. Acta Odontol Scand. 2012; 70(1): 56-60.

51. Maciel K, Carvalho R, Ringle R, Preston C, Russell C, Pashley DH. The effects of acetone, ethanol, HEMA, and air on the stiffness of human decalcified dentin matrix. J Dent Res. 1996; 75(11): 1851-8.

52. Sato C, Rodrigues F, Garcia D, Vidal C, Pashley $\mathrm{DH}$, Tjäderhane $\mathrm{L}$, et al. Tooth bleaching increases dentinal protease activity. J Dent Res. 2012; 92: 187-92.

53.Siqueira EL, dos Santos M, Neto JADG, dos Santos FLHV. Resıstência Ao Cisalhamento De Dentes Submetıdosa Duas Técnıcas De Clareamento, Pós-Restaurados Ou Não Shear Strength in Teeth Subjected to Two Bleaching Technıques, Post-Restoratıon or Otherwise. Rev Odontol Univ São Paulo. 1997; 11(s 1).

54.Lado E, Stanley H, Weisman M. Cervical resorption in bleached teeth. Oral Surg, Oral Med, Oral Pathol. 1983; 55(1): 78-80.

55. Harrington GW, Natkin E. External resorption associated with bleaching of pulpless teeth. $\mathrm{J}$ Endod. 1979; 5(11): 344-8.

56. Cvek M, Lindvall AM. External root resorption following bleaching of pulpless teeth with oxygen peroxide. Dent Traumatol. 1985; 1(2): 56-60.

57.Rotstein I. In vitro determination and quantification of $30 \%$ hydrogen peroxide penetration through dentin and cementum during bleaching. Oral Surg, Oral Med, Oral Pathol. 1991; 72(5): 602-6.

58.Dahl J, Pallesen U. Tooth bleaching a critical review of the biological aspects. Critical Reviews in Oral Biology \& Medicine. 2003; 14(4): 292-304.

59. Haywood VB. History, safety, and effectiveness of current bleaching techniques and applications of the nightguard vital bleaching technique. Quintessence Int. 1992; 23(7): 47188. 
60.Bowles WH, Ugwuneri Z. Pulp chamber penetration by hydrogen peroxide following vital bleaching procedures. J Endod. 1987; 13(8) :375-7.

61. Fuss Z, Szajkis S, Tagger M. Tubular permeability to calcium hydroxide and to bleaching agents. J Endod. 1989; 15(8): 362-4.

62.Özdemir F. Dental Florozisli Dişlerde Uygulanan Ofis Tipi Ağartma Yönteminde \%35'lik Hidrojen Peroksitin Pulpaya Etkilerinin in Vivo ve in Vitro Olarak İncelenmesi, Süleyman Demirel Üniversitesi Sağlık Bilimleri Enstitüsü. 2009.

63.Fugaro JO, Nordahl I, Fugaro OJ, Matis BA, Mjor I. Pulp reaction to vital bleaching. Oper Dent-Univercity of Washington. 2004; 29(4): 363-8.

64. George JR P, Zaidel L, Lin N, Stranick M, Bagley D. High Levels of Hydrogen Peroxide in Overnight Tooth-Whitening Formulas: Effects on Enamel and Pulp. J Esthet Restor Dent. 2005; 24(1): 1-58.

65. Bowles WH, Thompson LR. Vital bleaching: the effects of heat and hydrogen peroxide on pulpal enzymes. J Endod. 1986; 12(3): 108-12.

66. Seale NS, McIntosh JE, Taylor AN. Pulpal reaction to bleaching of teeth in dogs. J Dent Res. 1981; 60(5): 948-53.

67. Sulieman M, Rees J, Addy M. Surface and pulp chamber temperature rises during tooth bleaching using a diode laser: a study in vitro. Br Dent J. 2006; 200(11): 631-4.

68.Soares DG, Ribeiro APD, Lima AF, Sacono NT, Hebling J, Costa CAdS. Effect of fluoride-treated enamel on indirect cytotoxicity of a $16 \%$ carbamide peroxide bleaching gel to pulp cells. Braz Dent $\mathrm{J}$. 2013; 24(2): 121-7.

69. Oliver TL, Haywood VB. Efficacy of nightguard vital bleaching technique beyond the borders of a shortened tray. J Esthet Restor Dent. 1999; 11(2): 95-102.

70.70. Cooper JS, Bokmeyer TJ, Bowles WH. Penetration of the pulp chamber by carbamide peroxide bleaching agents. J Endod. 1992;18(7):315-7.

71.Rosenstiel SF, Gegauff AG, Johnston WM. Randomized clinical trial of the efficacy and safety of a home bleaching procedure. Quintessence Int. 1996; 27(6): 413-24.

72.Bonafé $E$, Bacovis $C L$, lensen $S$, Loguercio $A D$, Reis A, Kossatz S. Tooth sensitivity and efficacy of inoffice bleaching in restored teeth. J Dent. 2013; 41(4): 363-9.

73.Roderjan DA, Stanislawczuk R, Hebling J, da Souza Costa CA, Soares DG, Reis A, et al. Histopathological features of dental pulp tissue from bleached mandibular incisors. Mater Sci Eng. 2014; $4(6 \mathrm{~B})$.

74. de Souza Costa CA, Riehl H, Kina JF, Sacono NT, Hebling J. Human pulp responses to in-office tooth bleaching. Oral Surg, Oral Med, Oral Pathol, Oral Radiol, Endod. 2010;109(4):e59-e64.
75.Lin C-H, Chou T-M, Chen J-H, Chen J-H, Chuang $\mathrm{F}-\mathrm{H}$, Lee $\mathrm{H}-\mathrm{E}$, et al. Evaluation of the effect of laser tooth whitening. Int J Prosthodont. 2008; 21(5).

76. Moncada G, Sepúlveda D, Elphick K, Contente M, Estay J, Bahamondes V, et al. Effects of light activation, agent concentration, and tooth thickness on dental sensitivity after bleaching. Oper Dent. 2013; 38(5): 467-76.

77. Martin J, Fernandez E, Bahamondes V, Werner A, Elphick K, Oliveira Jr OB, et al. Dentin hypersensitivity after teeth bleaching with in-office systems. Randomized clinical trial. Am J Dent. 2013; 26(1): 10-4.

78. Tipton DA, Braxton SD, Dabbous MK. Role of saliva and salivary components as modulators of bleaching agent toxicity to human gingival fibroblasts in vitro. J Periodontol. 1995; 66(9): 76674.

79. Hayes P, Full C, Pinkham J. The etiology and treatment of intrinsic discolorations. J Can Dent Assoc. 1986; 52(3): 217.

80. Martin JH, Bishop JG, Guentherman RH, Dorman $\mathrm{HL}$. Cellular response of gingiva to prolonged application of dilute hydrogen peroxide. J Periodontol. 1968; 39(4): 208-10.

81.Leonard Jr RH, Haywood vB, Phillips C. Risk factors for developing tooth sensitivity and gingival irritation associated with nightguard vital bleaching. Quintessence Int. 1997; 28(8): 527-34.

82. Luque-Martinez I, Reis A, Schroeder M, Muñoz MA, Loguercio AD, Masterson $D$, et al. Comparison of efficacy of tray-delivered carbamide and hydrogen peroxide for at-home bleaching: a systematic review and meta-analysis. Clin Oral Inves. 2016; 20(7): 1419-33.

83.Sherman SJ, Boyer LV, Sibley WA. Cerebral infarction immediately after ingestion of hydrogen peroxide solution. Stroke-a Journal of Cerebral Circulation. 1994; 25(5): 1065-7.

84.Christensen DW, Faught WE, Black RE, Woodward GA, Timmons OD. Fatal oxygen embolization after hydrogen peroxide ingestion. Crit Care Med. 1992; 20(4): 543-4.

85. Robertson WD, Melfi RC. Pulpal response to vital bleaching procedures. J Endod. 1980; 6(7): 645-9.

Yazışma Adresi:

Prof. Dr. Ayşe Diljin KEÇECi

Süleyman Demirel Üniversitesi

Diş Hekimliği Fakültesi

Endodonti AD

Doğu Kampüsü, Isparta

Tel : +902462118782

E-mail: diljinkececi@gmail.com 